\title{
Population Decline of White Locoweed
}

\author{
By David Graham and Michael H. Ralphs
}

$\mathrm{M}$

any Astragalus and Oxytropis species are endemic (growing on specific soils and geographical areas), but white locoweed (Oxytropis sericea) is the most widespread locoweed in the western United States, growing on short-grass prairies and eastern foothills of the Rocky Mountains from Montana to New Mexico. Its preferred habitat is rocky soils, ${ }^{1}$ where its long taproot can access deep percolated water allowing it to survive drought, temperature, and wind stress. ${ }^{2}$

In spite of its stress-tolerant survival strategy, white locoweed populations appear to be affected by precipitation patterns. Marsh ${ }^{3}$ observed that white locoweed was particularly abundant in wet years, leading to the severe outbreak along the Rocky Mountain Front Range during the 1890s and early 1900s, resulting in catastrophic livestock losses; however, it nearly disappeared in dry years. Purvines and Graham ${ }^{4}$ surveyed ranchers in northeastern New Mexico and reported white locoweed was abundant in the wet years 1954-1962 following the great drought of the early 1950s, and then another major extended outbreak occurred from 1987 to 1996. Ralphs ${ }^{5}$ reported populations of white locoweed declined in New Mexico, Colorado, and Utah between 1995 and 2000. We maintained the transects from this previous clip study and established a series of new transects in northeastern New Mexico to monitor white locoweed populations and relate its change in density to precipitation patterns.

\section{Continuation of Clip Study}

The original transects from the clip study were located north of Fort Collins, Colorado (40 $\left.54^{\prime} 43^{\prime \prime} \mathrm{N}, 105^{\circ} 16^{\prime} 19^{\prime \prime} \mathrm{W}\right)$, and at Des Moines, New Mexico (36 $\left.45^{\prime} 13^{\prime \prime} \mathrm{N}, 103^{\circ} 51^{\prime} 00^{\prime \prime} \mathrm{W}\right)$ and were read from 1995 to 2000 . Clipping had no effect on mortality, but most plants (both defoliated and undefoliated plants) died over the 5-year study. We continued to monitor these transects through 2001, and resumed reading them in 2007-2009 following an apparent reestablishment of the locoweed plants. Transects were $1 \mathrm{~m}$ wide and 15-20 m long. Five transects were established at each location. The number of white locoweed plants in each transect was counted.

\section{Northeastern New Mexico Density Study}

In 1999, four additional sites were selected in Union and Colfax counties in northeast New Mexico: Sofia $\left(36^{\circ} 24^{\prime} 32^{\prime \prime} \mathrm{N}\right.$, $\left.104^{\circ} 09^{\prime} 50^{\prime \prime W}\right)$, Chico $\left(36^{\circ} 28^{\prime} 47^{\prime \prime} \mathrm{N}, 104^{\circ} 09^{\prime} 46^{\prime \prime} \mathrm{W}\right)$, Capulin $\left(36^{\circ} 42^{\prime} 30^{\prime \prime} \mathrm{N}, 104^{\circ} 02^{\prime} 45^{\prime \prime} \mathrm{W}\right)$, and Mesa $\left(36^{\circ} 54^{\prime} 38^{\prime \prime} \mathrm{N}\right.$, $\left.104^{\circ} 09^{\prime} 50^{\prime \prime} \mathrm{W}\right)$. At each site, a center point was marked with a metal fence post. A 30-m line was stretched in each of the four cardinal directions and the end point marked with a rebar stake. A 1-m belt transect was created by carrying a 1-m stick perpendicular to the line and counting the number of locoweed plants. The number of plants was converted to density per square meter. Correlations were run between locoweed densities and annual precipitation from the nearest weather station at each site in both studies.

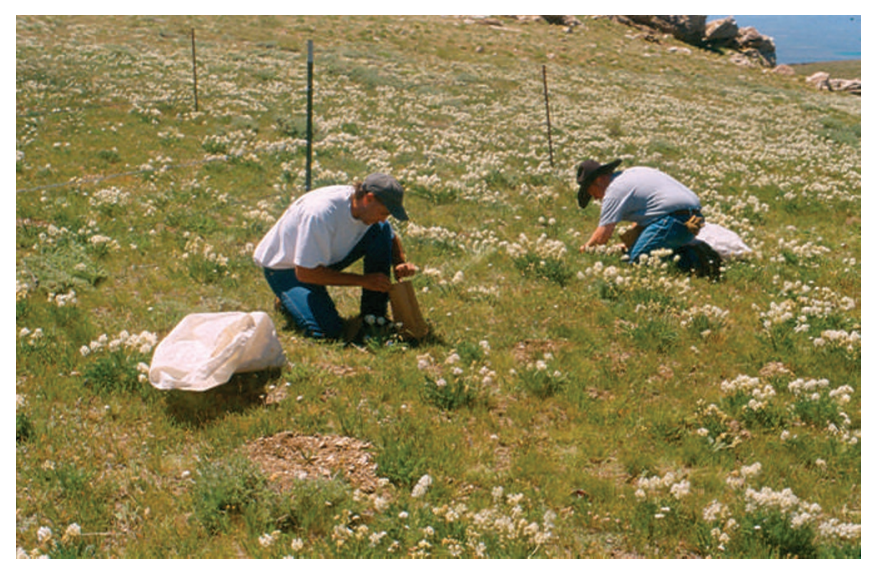

Researchers Derek Hinckley and Erik Thacker clipping white locoweed in the original locoweed clip study.

\section{White Locoweed Response to Drought}

Density of white locoweed was very high in northeastern New Mexico during the early 1990s. Our data show density of white locoweed dropped from 10 plants $/ \mathrm{m}^{2}$ (New Mexico) and 13 plants $/ \mathrm{m}^{2}$ (Colorado) in 1995, to 0 in 1999 and in 2000 in both locations and remained low through the region-wide drought (Fig. 1). When the transects were read in 2007-2009 the populations remained low (Fig. 1).

In the density study in northeastern New Mexico, white locoweed density increased slightly following above-average precipitation in 2004-2006. Density peaked in 2007 at 1.0 plant $/ \mathrm{m}^{2}$ at the two southern transects (Sofia and Chico), and 0.27 plants $/ \mathrm{m}^{2}$ at the two northern transects (Capulin and Mesa), then declined to near 0 in 2008 and 2009 (Fig. 


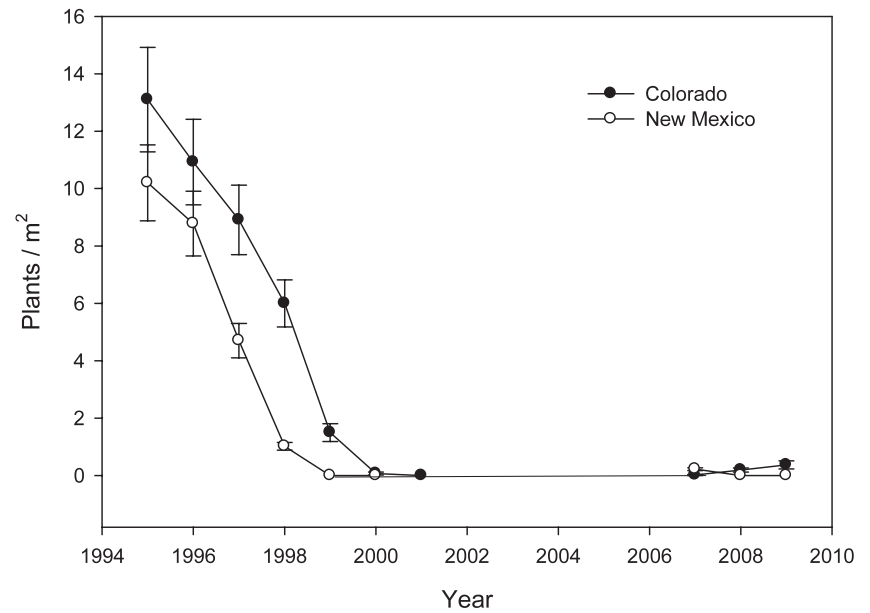

Figure 1. Density of white locoweed plants from the clip study transects in Colorado and New Mexico.

2). Though the correlations were not strong, ${ }^{i}$ the data suggest a trend of white locoweed plants increasing in density in response to the previous wet year. The seeds probably germinated during the wet seasons, and it took a year or two for the plants to grow and become apparent, accounting for the apparent lag of increasing density following wet years. The populations died back in years of below-average precipitation.

Similar results were reported by $\mathrm{McDaniel}$ et al. ${ }^{6}$ in a 13-year herbicide study seeking to eradicate white locoweed in northeastern New Mexico. At the beginning of their study in 1992, white locoweed density was 1.7 plants $/ \mathrm{m}^{2}$. In the untreated control plots, white locoweed density declined over time to 0.7 plants $/ \mathrm{m}^{2}$ in 1996 . Density increased slightly following above-average summer precipitation in 1997, then dropped to 0.4 plants $/ \mathrm{m}^{2}$ in 2003-2005. This last decline was similar to the decline we observed in our northeastern New Mexico study between 2002 and 2004 (Fig. 2). White locoweed plants that emerged from seed were sprayed on four occasions over 13 years, yet the authors were still not sure the locoweed seed source was exhausted in the soil. ${ }^{6}$

Species of Astragalus also appear to cycle with precipitation. Outbreaks of Wahweap milkvetch (Astragalus lentiginosus var. wabweapensis) occurred every 6-8 years between 1946 and 1986 and were associated with above-average fall and spring precipitation. ${ }^{7}$ Populations of Green River milkvetch (Astragalus pubentisimus) were high in 1917-1918, 19571958, and 1965-1966 in the Uintah Basin in eastern Utah, resulting in catastrophic sheep losses. ${ }^{8}$ Woolly locoweed (Astragalus mollissimus) is widespread throughout western Kansas, Oklahoma, and eastern New Mexico and western Texas. However, it rarely persists more than 2 to 3 years because of reoccurring droughts and from damage inflicted by the

i $r=0.35-0.57$

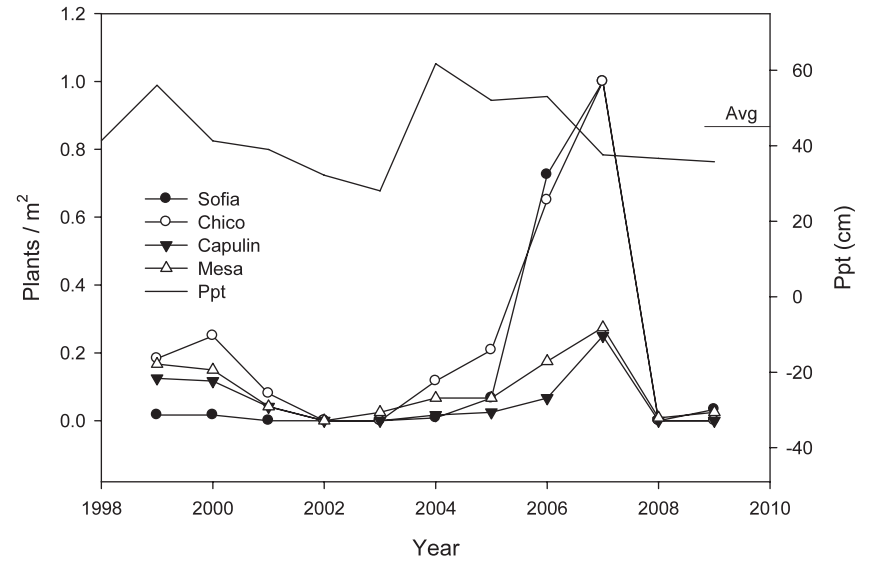

Figure 2. Density of white locoweed from the Transect Study in northeastern New Mexico, and annual precipitation.

four-lined locoweed weevil (Cleonidius trivittatus). ${ }^{9}$ A closely related weevil has been found on white locoweed in north central Colorado and southeastern Wyoming, but its effects on white locoweed populations is unknown.

Many locoweed species have large seed banks in the soil $\left(600-4,000 / \mathrm{m}^{2}\right){ }^{7,10}$ The seeds have hard coats that allow them to remain viable for many years. Germination rate of white locoweed seed collected in northwestern Utah in 1984 and stored in the lab was $86 \%$, and the locoweed endophyte (Undifilum oxytropis) was viable in $80 \%$ of these seed after 35 years. ${ }^{11}$ The hard seed coat allows them to remain in the soil for many years and provides them the ecological advantage to exploit environmental conditions and maintain the "boom and bust" population cycles.

\section{Conclusions}

White locoweed populations apparently increase following wet years, and die back during drought. This study documented a complete die-off of white locoweed at study sites in New Mexico and Colorado. Observations of the authors con-

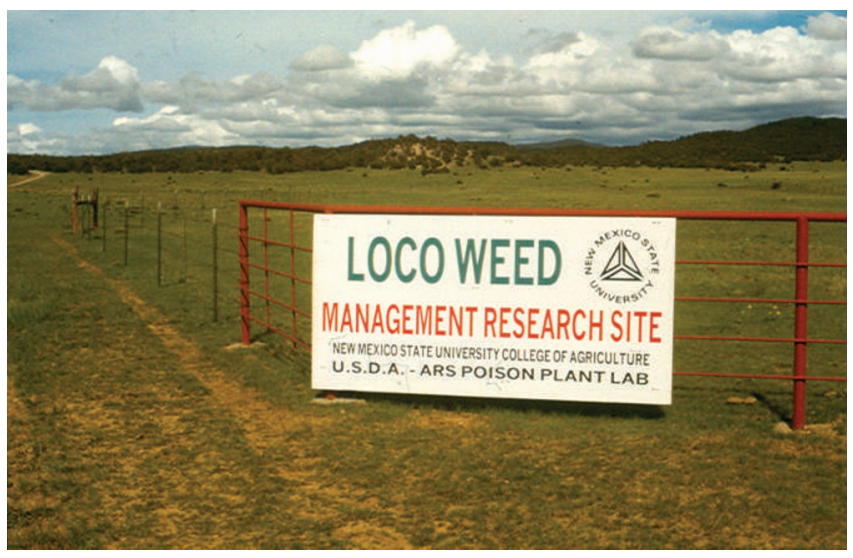

Cooperative locoweed research between New Mexico State University and US Department of Agriculture/Agricultural Research Service Poisonous Plant Lab in northeastern New Mexico from 1991 to 2010. 
firmed the die-back of white locoweed populations throughout its distribution on the Western plains and mountains between 1995 and 2000. There was no reestablishment during the region-wide drought of the early 2000s. Density of white locoweed increased slightly in northeastern New Mexico in 2006 and 2007, but it did not continue because of below-average precipitation in 2008 and 2009. It would be important for ranchers and managers to monitor rangelands for 2 or 3 years following wet years to detect emergence of white locoweed populations. We expect outbreaks of white locoweed will occur in the future when environmental conditions are conducive, as has been observed in the past (late 1890s, late 1950s, 1987-1998).

\section{Acknowledgments}

David Graham (1944-2011) was the Extension County Agent in Union County, New Mexico, for over 40 years. For the last 20 years, David dedicated a good part of his time to the locoweed problem in the region. In 1990, he was instrumental in organizing the ranchers, university administrators, and state and national legislators to apply for and receive a Congressional grant for locoweed research. The USDA-ARS Poisonous Plant Lab and New Mexico State University worked closely together researching all aspects of locoweed ecology, control, and grazing management. David was the "on the ground" member of the research team who identified the problem, located a ranch that was willing to allow the research, and took care of all the logistical problems of conducting research in the field. This paper represents a research project David conducted by monitoring white locoweed populations in northeastern New Mexico over 15 years.

\section{References}

1. Payne, G. F. 1957. Ecology and life history of the poisonous plant, white locoweed (Oxytropis sericea Nutt.). [dissertation]. College Station, TX, USA: Texas A\&M University. 100 p.

2. Ralphs, M. H., B. Benson, And J. C. Loerch. 1989. Soil-site relationships of white locoweed on the Raft River mountains. Great Basin Naturalist 49:419-424.
3. Marsh, C. D. 1909. The loco-weed disease of the plains. Washington, DC, USA: USDA Bureau of Animal Industries. Bulletin $112.130 \mathrm{p}$.

4. Purvines, J., and D. Graham. 1999. When rain falls may affect locoweed density. In: T. M. Sterling and D. C. Thompson [EDs.]. Locoweed research updates and highlights. Las Cruces, NM, USA: New Mexico State University Agricultural Experiment Station. Research Report 730. p. 32-33.

5. Ralphs, M. H., D. R. Gardner, J. D. Graham, G. Greathouse, AND A. P. Knight. 2002. Clipping and precipitation influences on locoweed vigor, longevity and toxicity. Journal of Range Management 55:394-399.

6. McDaniel, K. C., T. Sterling, and S. Ivey. 2007. Herbicidal control of locoweed. In: K. E. Panter, T. L. Wierenga, and J. A. Pfister [EDs.]. Poisonous plants: global research and solutions. Wallingford, UK: CABI Publishing. p. 351-358.

7. Ralphs, M. H., and V. L. Bagley. 1988. Population cycles of Wahweap milkvetch on the Henry Mountains and seed reserve in the soil. Great Basin Naturalist 48:541-547.

8. James, L. F., K. L. Bennett, K. G. Parker, R. F. Keeler, W. Binns and B. Lindsay. 1968. Loco plant poisoning in sheep. Journal of Range Management 21:360-365.

9. Thompson, D. C., J. L. Knight, and T. S. Sterling. 1995. Preference for specific varieties of woolly locoweed by a specialist weevil, Cleonidius trivittatus (Say). Southwestern Entomologist 20:325-333.

10. Ralphs, M. H., And E. H. Cronin. 1987. Locoweed seed concentration in soil: longevity, germination potential and viability. Weed Science 35:792-795.

11. Oldrup, W., J. Mclain-Romero, A. Padilla, A. Moya, D. Gardner, and R. Creamer. 2010. Localization of endophytic Undifilum fungi in locoweed seed and influence of environmental parameters on a locoweed in vitro culture system. Botany 88:512-521.

Authors are County Agent, New Mexico State University Extension, Clayton, NM 88415, USA (Graham, deceased); and Rangeland Scientist, USDA-ARS Poisonous Plant Lab, Logan, UT 84341, USA, Michael.Ralphs@ars.usda.gov (Ralphs). 